\title{
Influence of progesterone ear implant on behavior, physiological parameters, and carcass injuries of Nellore females reared in an intensive system
}

\author{
Rafael Alves da Costa Ferro', Aldi Fernandes de Souza França², Emmanuel Arnhold ${ }^{2}$, Cláudia \\ Peixoto Bueno', Diogo Alves da Costa Ferro', Aracele Pinheiro Pales', Klayto José Gonçalves \\ dos Santos ${ }^{1}$, Bruna Paula Alves da Silva ${ }^{1}$
}

\author{
${ }^{1}$ Universidade Estadual de Goiás, São Luís de Montes Belos, GO, Brazil. \\ 2 Universidade Federal de Goiás, Escola de Veterinária e Zootecnia, Goiânia, GO, Brazil.
}

\begin{abstract}
The objective of this study was to evaluate the influence of a synthetic progesterone ear implant on the behavior, physiological responses, and number of carcass injuries of Nellore females. Twenty-eight Nellore heifers with an average initial weight of $240.89 \mathrm{~kg}$ were used in the experiment. All animals received the same dietary management, in an intensive rearing system with mineral salt and water ad libitum. Heifers were distributed in a completely randomized design with two treatments (with and without progesterone ear implant) and seven replications, in 14 stalls. Analyses of variance and correlation were performed. In the evaluation of the feeding, rumination, rest, sleeping, social, and body-care behaviors, no significant differences were observed. The use of ear implant did not change weight gain or the number of injuries on the carcass of Nellore females. There was a greater incidence of anomalous behavior for the animals without the implant. Other behaviors were not affected by the hormone. As regards the physiological responses, only respiratory frequency was influenced by the implant. The behavior and performance of heifers are not influenced by progesterone ear implant.
\end{abstract}

Key Words: animal performance, ethology, hormone, norgestomet

\section{Introduction}

Brazil has a prominent place in the world rank of animal protein production, with a bovine herd of approximately 209 heads. The largest part of this herd consists of Nellore (Abiec, 2015), a breed with characteristics favorable to adaptation, such as short hair, pigmented skin, and light hair coat, which provide it with greater protection against solar radiation and thermal stress, resulting in higher comfort and better production performance (Silva, 2000).

Today, consumers are increasingly demanding in terms of food quality, besides their concern with animal welfare. The term 'welfare' should be linked to other concepts, such as happiness, needs, suffering, freedom, feelings, pain, fear, health, stress, and adaptation (Broom and Molento, 2004).

Several factors can lead the animal to stress, some of which are body temperature, availability of water and shade, and behavioral responses to climatic elements, which directly affect the heat exchanges with the environment (Navarini et al., 2009).

Received August 26, 2015 and accepted April 4, 2016 Corresponding author: rafael1zoo@hotmail.com

http://dx.doi.org/10.1590/S1806-92902016000700005

Copyright (C) 2016 Sociedade Brasileira de Zootecnia. This is an Open Access article distributed under the terms of the Creative Commons Attribution License (http://creativecommons.org/licenses/by/4.0/), which permits unrestricted use, distribution, and reproduction in any medium, provided the original work is properly cited.
Behavioral and physiological assessments can be used to evaluate welfare, because when alterations occur aiming at homeothermy, low welfare conditions are inferred (Broom and Molento, 2004). In these assessments, the fact that the animal drinks water, consumes foods, rests idle, or escapes may be characterized as the part or entirety of a behavior (Del-Claro, 2004).

Broom and Fraser (2010) reported that animals that have the opportunity to interact socially with other species or that are kept with other members of its own species sometimes display anomalous behavior. When kept in a group of only one sex, they may develop at a higher frequency the anomalous behavior of sodomy, which consists of the attempt of coitus that can lead to carcass losses due to injuries.

This problem can be solved when the animal is pregnant due to the larger amount of progesterone that prompts a negative feedback from the reproductive hormones, consequently not having negative effects on the meat quality (Hafez et al., 2004).

In addition to natural production, some synthetic progestagens are available to ruminants, and these can be administered orally, intravaginally, and auricularly (Hafez et al., 2004). These progestagens are used when their action (replacement) is desired as a false corpus luteum, when it is not present, or to strengthen the action of the present corpus luteum (Ferreira, 2012). 
This study aimed to evaluate the influence of a synthetic progesterone ear implant on the behavior, physiological responses, and number of carcass injuries of Nellore females.

\section{Material and Methods}

The experiment was conducted in São Luís de Montes Belos-GO, Brazil (16 $31^{\circ} 20^{\prime \prime} \mathrm{S}$ and $\left.50^{\circ} 22^{\prime} 48^{\prime \prime} \mathrm{W}\right)$, where the average temperature and humidity during the experimental period (May to June 2014) were $25{ }^{\circ} \mathrm{C}$ and $52 \%$, respectively, measured using a thermo-hygrometer. Experimental procedures complied with and were approved by the Ethics Committee on Animal Use (CEUA) of Universidade Federal de Goiás.

Twenty-eight Nellore heifers (Bos indicus), all in estrus, at an average age of 20 months, were kept in the feedlot for 60 days, managed in 14 stalls with two heifers per stall, belonging to the same treatment, and distributed at random. The same environment was provided to all animals, and each stall measured $24 \mathrm{~m}^{2}$.

The experiment was conducted as a completely randomized design with two treatments (with and without progesterone ear implant) and seven replications, using 14 stalls, with two animals per stall.

Upon entering the feedlot, 14 females received a progesterone ear implant (with three milligrams of norgestomet) subcutaneously. The implant was changed every 15 days so that the plasma progesterone concentration would not be lost, and animals had them on until 15 days before the slaughter. The group with ear implant had an average initial weight of $243.92 \mathrm{~kg}$, while that without the implant weighed $237.85 \mathrm{~kg}$, on average.

Corn silage was supplied during the entire confinement period, together with a concentrate containing ground corn, soybean meal, soybean hulls, livestock urea, and a mineral-vitamin mix. Feed was supplied four times daily, distributed at $06.00 \mathrm{~h}, 10.00 \mathrm{~h}, 13.00 \mathrm{~h}$, and $17.00 \mathrm{~h}$, with feed intake monitored.

At every 15 days, all experimental animals were taken to the management corral to have their rectal temperature (RT) measured and live weight controlled, using a digital scale placed immediately after the restraint chute, which allowed us to check the influence of the progesterone hormone on the final weight, total weight gain, and average daily weight gain.

Rectal temperature was measured using a clinical thermometer graduated from 33 to $45{ }^{\circ} \mathrm{C}$ that was inserted in the rectum of the heifers and left for two minutes. The body surface temperature, in turn, was measured biweekly, at $13.00 \mathrm{~h}$, using a portable digital infrared thermometer in the flank region.

To evaluate the behavior of the animals, the responsible team was previously trained, remaining at a distance of seven meters from the stalls so as not to influence the behavioral responses of the animals. The team consisted of members responsible for providing the feed, since the animals were already accustomed to their presence.

Behavior was assessed biweekly, on days different from the weighing sessions, by a visual observation for twelve continuous hours, beginning at $06.00 \mathrm{~h}$ and ending at $18.00 \mathrm{~h}$. Feeding, rumination, rest, sleeping, social, bodycare, and anomalous behaviors were observed (Table 1).

Together with the evaluation of the behavior, the respiratory frequency (RF) was measured at $06.00 \mathrm{~h}$, $12.00 \mathrm{~h}$, and $18.00 \mathrm{~h}$. For the record of RF, the number of respirations per minute was counted, observing the oscillations of the left flank of the animal for one minute. For the same times, temperature and humidity data were collected for subsequent analysis of correlation with respiratory frequency.

The animals were slaughtered in a slaughterhouse according to the current legal procedures (Brasil, 2007). Heifers were stunned by brain concussion with a captive bolt pistol, which aims at rendering the animal unconscious during slaughter so that it can be killed efficiently in a painless manner, remaining immobilized to be suspended for the subsequent bleeding by sectioning the large vessels. After the slaughter, carcasses were weighed and identified by tags with the number of the animal. Next, the number of injuries on the carcasses was counted, comparing females with and without the progesterone ear implant. The color

Table 1 - Behavioral parameters evaluated during the experimental period

\begin{tabular}{ll}
\hline Behavior category & \multicolumn{1}{c}{ Description } \\
\hline Feeding & Animal observed feeding \\
Rumination & $\begin{array}{l}\text { Process by which the already swallowed feed } \\
\text { returns to the mouth so that the particles can } \\
\text { be broken down again by movements provided } \\
\text { by chewing }\end{array}$
\end{tabular}

Rest and sleep Animal lying resting or sleeping

Social

Animal playing, rubbing, overpowering, or in contact with other animal(s)

Body care

Acts of cleaning other animals, self-cleaning, urinating, defecating, and rubbing on itself

Anomalous

Related to stereotypies; anomalous behavior towards itself, the environment, or another animal 
of the injuries was also checked, with intense red meaning recent injuries caused by the transport of the animals to the slaughterhouse.

Computer software R (version 2.15.2) was used for the statistical analyses, allowing a comparison of performance, behavior, and physiological parameters of the two treatments, with analysis of variance. Correlation analysis was also performed between respiratory frequency and the climatic elements temperature and relative humidity.

\section{Results and Discussion}

The initial and final weight of the animals in the treatments with and without the ear implant were similar (333.63 kg and $331.46 \mathrm{~kg}$ ) (Table 2), with no significant statistical differences $(\mathrm{P}>0.05)$.

Comparing the groups (implant or lack thereof), no statistical difference was detected $(\mathrm{P}>0.05)$ in the mean values for the feeding, resting, ruminating, and other behavioral activities (Table 3 ).

Pinto et al. (2010) asserted that the rumination and feeding behaviors are influenced by several factors, such as chemical and physical properties of the diet, degradability and digestibility of the diet, and individual characteristics of each animal. This fact explains the lack of significant differences between the treatments, in the present study, in relation to the feeding and rumination behaviors, with respective mean values of $196.5 \mathrm{~min}$ and $157.75 \mathrm{~min}$. The feeding and rumination behaviors were not affected by the hormonal level, and were more subject to variations in dietary properties.

Table 2 - Mean values for initial and final weight of Nellore heifers with and without ear implant

\begin{tabular}{llllll}
\hline \multirow{2}{*}{ Treatment } & \multicolumn{2}{c}{ Implant } & & & \\
\cline { 2 - 4 } & Without & With & & & \\
& Initial weight, kg & SD & CV (\%) & P-value \\
Final weight, kg & 237.85 & 243.92 & $240.88 \pm 14.16$ & 5.87 & 0.32 \\
\hline
\end{tabular}

Not significant $(\mathrm{P}>0.05)$

$\mathrm{SD}$ - standard deviation; CV - coefficient of variation.

Table 3 - Mean values for the feeding, resting, rumination, and other behavioral activities of Nellore heifers with and without ear implant

\begin{tabular}{lccccc}
\hline \multirow{2}{*}{ Treatment } & \multicolumn{2}{c}{ Implant } & & & \\
\cline { 2 - 4 } & Without & With & & & \\
& 194.50 & 198.50 & $196.50 \pm 26.59$ & 13.53 & 0.81 \\
Feeding, min & 436.83 & 445.96 & $441.39 \pm 25.81$ & 5.85 & 0.56 \\
Resting, min & 156.67 & 158.83 & $157.75 \pm 41.52$ & 26.32 & 0.93 \\
Rumination, min & 88.67 & 75.54 & $82.10 \pm 16.96$ & 20.65 & 0.81 \\
\hline
\end{tabular}

Not significant $(\mathrm{P}>0.05)$.

$\mathrm{SD}$ - standard deviation; CV - coefficient of variation.
Souza et al. (2011) reported feeding behavior lasting $520 \mathrm{~min}$ and rumination of $503 \mathrm{~min}$, in $24 \mathrm{~h}$, in a study with heifers reared on pasture. The amount of solid feed, especially fibrous feedstuffs, supplied to the animals, is directly related to the duration of rumination. In the period of $24 \mathrm{~h}$, an animal ruminates 15 to 20 times, which may last a few minutes in each period or go on for over an hour. Rumination can also be influenced by estrus, almost always declining (Broom and Fraser, 2010).

Analyzing the rest behavior, no significant differences were observed between the treatments, which averaged $441.4 \mathrm{~min}$ in the period of $12 \mathrm{~h}$. Lower values were observed by Souza et al. (2011), for grazing heifers, which spent 417 min resting over a period of $24 \mathrm{~h}$. These authors observed that the progesterone hormone does not affect the rest time of the animals, which is a behavior influenced by the rearing system and environmental conditions. According to Degasperi et al. (2003), the animal rest is of extreme importance for its integration with the environment and contributes to the physiological functions; around $80 \%$ of the rumination occurs with the animal resting or lying. Rest time varies according to the available area, type of facility, climatic factors, and type of diet.

No significant differences were observed between the treatments $(\mathrm{P}>0.05)$ concerning the frequencies of water consumption, urination, defecation, cleaning others, social, and self-cleaning behaviors (Table 4).

The animals from both treatments expressed body cleaning, cleaning others, and self-cleaning behaviors. As regards the latter, acts like licking its own body, rubbing the head on its paw, and rubbing itself on the post and on the stall fence were observed. For the behavior of cleaning others, a larger number of mutual licking acts were observed, considered a normal behavior. For Broom and Fraser (2010), the lack of significant differences between the treatments with and without the ear implant is attributed to the fact that cattle in long-lasting groups form cleaning partners, which is a behavior considered normal for the species.

Table 4 - Mean values for the frequency of behaviors displayed by Nellore heifers with and without ear implant

\begin{tabular}{lccccc}
\hline \multirow{2}{*}{ Treatment } & \multicolumn{2}{c}{ Implant } & & \\
\cline { 2 - 4 } & Without & With & & & \\
Water consumption & 10.67 & 11 & $10.84 \pm 2.96$ & 27.31 & 0.63 \\
Urination & 3 & 3.5 & $3.25 \pm 1.27$ & 39.07 & 0.66 \\
Defecation & 4.16 & 4.5 & $4.33 \pm 1.42$ & 32.79 & 0.69 \\
Anomalous & 2.3 & 1.3 & $1.80 \pm 0.51$ & 28.33 & 0.007 \\
Cleaning others & 2.5 & 2.17 & $2.34 \pm 0.48$ & 20.51 & 0.25 \\
Social & 15.8 & 12.83 & $14.32 \pm 2.51$ & 17.52 & 0.08 \\
Self-cleaning & 7.1 & 7.5 & $7.30 \pm 0.65$ & 8.90 & 0.40 \\
\hline
\end{tabular}

Not significant $(\mathrm{P}>0.05)$.

$\mathrm{SD}$ - standard deviation; CV - coefficient of variation. 
Mean values for urination and defecation frequencies of the treatments were 3.25 and 4.33, respectively, in the 12 -h period. Similar results were found by Degasperi et al. (2003), who observed daily frequencies of 4.32 for defecation and 4.67 for urination, considered normal values for physiological frequencies.

According to Broom and Fraser (2010), cattle usually defecate 12 to 18 times and urinate approximately nine times in a 24-h period; however, this frequency varies according to the amount and nature of the ingested feedstuff, the animal itself, and the ambient temperature, not depending on the progesterone levels.

In both treatments, animals from the same stall had social interactions, with no significant differences detected for social behavior. According to Grandin and Johnson (2010), cattle are herd animals, and so interacting with their companions is a normal behavior.

No significant differences were observed for water consumption between the treatments with and without the ear implant, considering that the animals were subjected to the same environment. Marques et al. (2006) stated that animals change this behavior according to climatic elements, explaining the inexistence of significant differences in the present experiment for the frequency of water consumption, which averaged 10.84 times in a period of $12 \mathrm{~h}$. Thus, it is extremely important to provide clean, fresh water, since its ingestion is essential for the physiological activities executed by animals (Ferreira, 2005).

Analyzing the groups with and without the implant, significant statistical differences were observed $(\mathrm{P}<0.05)$ for anomalous behavior, whose frequencies were 1.3 and 2.3 times, respectively. Among the main anomalous behaviors observed are sodomy, wire biting, geophagia, and lignophagia, the first having the highest frequency. Heifers without the auricular implant showed a higher frequency of this behavior, explained by the action of reproductive hormones, like estrogen, responsible for the manifestation of heat.

Broom and Fraser (2010) claimed that the sodomy behavior is very frequent in groups of cows and heifers, and that it can lead to injuries, serious economic losses, decreased growth rate, and low welfare of mounted animals.

During post-slaughter, some injuries were observed on the carcasses of the heifers, likely caused by the transport from the feedlot to the slaughterhouse, but no differences were detected between treatments resulting from the use of auricular implant.

The road transportation of cattle to the slaughterhouse has a great influence on the incidence of carcass injuries, which are related to the distance traveled and the quality of roads. In their studies, Andrade et al. (2008) found that of a total of 121 carcasses, 102 displayed one or more injuries.

For rectal temperature (RT), no significant statistical differences $(\mathrm{P}>0.05)$ were noted between the heifers with and without the progesterone ear implant, with respective mean values of 38.52 and $38.54{ }^{\circ} \mathrm{C}$, and the average value of $38.53{ }^{\circ} \mathrm{C}$, considered within the physiological limit (Table 5). These results agree with the statement of Silva (2000), that the amplitude of the rectal temperature of zebu cattle varies from 38.5 to $39.7{ }^{\circ} \mathrm{C}$ in thermoneutral conditions, delimited by the critical lower temperature of $7{ }^{\circ} \mathrm{C}$ and critical upper temperature of $35^{\circ} \mathrm{C}$. Shiota et al. (2013) obtained a RT of $39.35^{\circ} \mathrm{C}$ in their experiment with Nellore heifers, whereas Barbosa et al. (2014) reported an average value of $39.5^{\circ} \mathrm{C}$, at an ambient temperature of $34.5^{\circ} \mathrm{C}$, observing excellent adaptation of the breed to the Brazilian environmental conditions.

Comparing the groups with and without the implant, no statistical difference $(\mathrm{P}>0.05)$ was found for the variable surface temperature (ST), with respective values of 37.27 and $38.39^{\circ} \mathrm{C}$. Shiota et al. (2013) found a lower value for surface temperature compared with the present study, of $36.6^{\circ} \mathrm{C}$, in the middle thoracic region. Navarini et al. (2009) observed a $0.9{ }^{\circ} \mathrm{C}$ increase in ST in the dorsal region of Nellore heifers exposed to direct solar radiation compared with shaded animals, whose values were 35.2 and $34.3{ }^{\circ} \mathrm{C}$, respectively. Lower values were found by Barbosa et al. (2014), with surface temperatures of $33.3,33.5$, and $34.3^{\circ} \mathrm{C}$ for the regions of the back, middle third of neck, and rump of Nellore cattle, respectively.

According to Ferreira et al. (2006), the surface temperature is influenced by the climatic elements temperature and humidity and physiological conditions like evaporation through sweating and vascularization.

The Zebu have some morphological and physiological characteristics that help in their adaptation to the tropics, like better ability to autoregulate their body heat. In their evolutionary process, they adapted to several conditions, with short hair adherent to their skin, and abundant

Table 5 - Mean values for rectal temperature, surface temperature, and respiratory frequency (RF) of Nellore heifers with and without ear implant

\begin{tabular}{|c|c|c|c|c|c|}
\hline \multirow{2}{*}{ Treatment } & \multicolumn{2}{|c|}{ Implant } & \multirow{2}{*}{ Mean $\pm \mathrm{SD}$} & \multirow{2}{*}{$\mathrm{CV}(\%)$} & \multirow{2}{*}{ P-value } \\
\hline & Without & With & & & \\
\hline Rectal temperature, ${ }^{\circ} \mathrm{C}$ & 38.54 & 38.52 & $38.53 \pm 0.44$ & 1.14 & 0.93 \\
\hline Surface temperature, ${ }^{\circ} \mathrm{C}$ & 38.39 & 37.27 & $37.83 \pm 1.49$ & 3.94 & 0.18 \\
\hline RF, mov. $\min ^{-1}$ & 32 & 35 & $33.50 \pm 1.90$ & 5.67 & 0.03 \\
\hline
\end{tabular}

Not significant $(\mathrm{P}>0.05)$.

$\mathrm{SD}$ - standard deviation; CV - coefficient of variation. 
secretion from their numerous and large sweat glands (Domingues, 1977).

Based on the results presented for respiratory frequency, significant differences were observed between the treatments with and without the progesterone implant, whose respective mean values were 35 and 32 movements per minute, which is within the physiological range. This increased respiratory frequency can be explained by the fact that progesterone is a lipophilic hormone, a heavy molecule, and thus the blood transport alters the heartbeat and consequently the respiratory frequency. These data were corroborated by Dirksen et al. (1993), who found values considered normal for respiratory frequency for adult cattle: 24 to 26 movements per minute. Values similar to those of this study were reported by Shiota et al. (2013), with Nellore heifers that showed a RF of 32.5 movements per minute, at an average temperature of $24.33{ }^{\circ} \mathrm{C}$ and relative humidity of $45 \%$. Barbosa et al. (2014) found a lower value for RF, an average of 25.7 movements per minute, at an ambient temperature of $34.5{ }^{\circ} \mathrm{C}$ and relative humidity of $72.5 \%$.

High, significant correlations of 0.75 and 0.78 were found between respiratory frequency and the climatic elements temperature and humidity, respectively. At higher temperatures, animals increase their respiratory frequency as a latent mechanism of heat dissipation to maintain their body temperatures (Table 6).

In order to expel a larger amount of hot air into the environment and dissipate the excess body heat, the animal increases its respiratory frequency per minute. This is only possible because of its ability to increase the volume of air inhaled and exhaled, exchanging a larger volume of air per unit of respiratory movement, expelling water into the environment, with a consequent expenditure of 585 cal. However, the efficiency of this process is reduced in regions with high relative humidity, because the air will be more saturated with the suspending water, reducing the ability to retain new quantities (Ferreira, 2005).

During the experimental period, average temperature and humidity of $25{ }^{\circ} \mathrm{C}$ and $52 \%$, respectively, were observed; these values are within the thermal comfort zone

Table 6 - Phenotypic correlation values for respiratory frequency of Nellore heifers and ambient temperature and humidity

\begin{tabular}{lccc}
\hline & $\begin{array}{c}\text { Respiratory } \\
\text { frequency }\end{array}$ & Temperature & Humidity \\
\hline Respiratory frequency & 1 & $0.75^{* *}$ & $0.78^{* *}$ \\
Temperature & & 1 & $0.95^{* *}$ \\
Humidity & & 1 \\
\hline
\end{tabular}

**Significant $(\mathrm{P}<0.05)$. for the animals. According to Ferreira (2005), for an adult Zebu animal, this variable should range from 10 to $27^{\circ} \mathrm{C}$, with upper and lower critical temperatures of 35 and $0{ }^{\circ} \mathrm{C}$, respectively, and relative humidity of 40 to $70 \%$ for most domesticated species.

\section{Conclusions}

The use of ear implant does not change weight gain or the number of injuries on the carcass of Nellore females. The behavior and performance of heifers are not influenced by progesterone ear implant.

\section{References}

ABIEC - Associação Brasileira das Indústrias Exportadores de Carne. Rebanho bovino brasileiro. 2015. Online. Available at: $<$ http://www.abiec.com.br/3 rebanho.asp>. Accessed on: Jul. 17, 2015.

Andrade, E. N.; Silva, R. A. M. S.; Roça, R. O.; Silva, L. A. C.; Gonçalves, H. C. and Pinheiro, R. S. B. 2008. Ocorrência de lesões em carcaças de bovinos de corte no Pantanal em função do transporte. Ciência Rural 38:1991-1996.

Barbosa, B. R. P.; Santos, S. A.; Abreu, U. G. P.; Egito, A. A.; Comastri Filho, J. A.; Juliano, R. S.; Paiva, S. R. and McMannus, C. 2014. Tolerância ao calor em bovinos das raças Nelore branco, Nelore vermelho e Pantaneira. Revista Brasileira de Saúde e Produção Animal 15:854-865.

Brasil. 2007. Inspeção de carnes bovina: padronização de técnicas, instalações e equipamentos. Ministério da Agricultura, Pecuária e Abastecimento, Poder Executivo, Brasília, DF, novembro de 2007.

Broom, D. M. and Fraser, A. F. 2010. Comportamento e bem-estar de animais domésticos. 4.ed. Manole, Barueri.

Broom, D. M. and Molento, C. F. M. 2004. Bem estar animal: conceito e questões relacionadas. Archives of Veterinary Science 9:1-11.

Degasperi, S. A. R.; Coimbra, C. H.; Pimpão, C. T.; Souza, F. P.; Chi, K. D.; Glaser Junior, P.; Macedo, R. E. F.; Piekarski, P. R. B.; Almeida, R.; Barbosa, A.; Karan, W. M.; Pereira, A. T.; Huber, A. R.; Ferreira, A. J. M.; Morestto, C. J.; Scholz, D.; Mercer, E. A.; Manzini, E.; Jazar, F. W.; Zoccoli, G.; Toledo, I.; Paula, M.; Janzen, P.; Napoli, R.; Kleig, S. and Costa, T. S. 2003. Estudo do comportamento do gado holandês em sistema de semi-confinamento. Revista Acadêmica Ciências Agrárias e Ambientais 1:41-47.

Del-Claro, K. 2004. Comportamento animal: Uma introdução à ecologia comportamental. Livraria Conceito, Jundiaí.

Dirksen, G.; Grunder, H. D. and Stober, M. 1993. Exame clínico dos bovinos. Guanabara Koogan, Rio de Janeiro.

Domingues, O. 1977. O Zebu, sua reprodução e multiplicação dirigida. 5.ed. Nobel, São Paulo.

Ferreira, A. M. 2012. Manejo reprodutivo de bovinos leiteiros: práticas corretas e incorretas, casos reais, perguntas e respostas. Edição do autor, Juiz de Fora.

Ferreira, F.; Pires, M. F. A.; Martinez, M. L.; Coelho, S. G.; Carvalho, A. U.; Ferreira, P. M.; Facury Filho, E. J. and Campos, W. E. 2006. Parâmetros fisiológicos de bovinos cruzados submetidos ao estresse calórico. Arquivo Brasileiro de Medicina Veterinária e Zootecnia 58:732-738.

Ferreira, R. A. 2005. Maior produção com melhor ambiente para aves, suínos e bovinos. Aprenda Fácil, Viçosa, MG. 
Grandin, T. and Johnson, C. 2010. O bem-estar dos animais: proposta de uma vida melhor para todos os bichos. Rocco, Rio de Janeiro.

Hafez, E. S. E.; Jainudeen, M. R. and Rosnina, Y. 2004. Hormônios, fatores de crescimento e reprodução. p.33-53. In: Reprodução animal. 7.ed. Hafez. E. S. E. and Hafez, B., eds. Manole, Barueri.

Marques, J. A.; Caldas Neto, S. F.; Groff, A. M.; Simonelli, S. M.; Corasa, J.; Romero, L.; Zawadski, F. and Araújo, P. F. 2006. Comportamento de bovinos mestiços em confinamento com e sem acesso a sombra durante o período de verão. Campo Digital 1:54-59.

Navarini, F. C.; Klosowski, E. S.; Campos, A. T.; Teixeira, R. A. and Almeida, C. P. 2009. Conforto térmico de bovinos da raça Nelore a pasto sob diferentes condições de sombreamento e a pleno sol. Engenharia Agrícola 29:508-517.
Pinto, A. P.; Marques, J. A.; Abrahão, J. J. S.; Nascimentos, W. G.; Costa, M. A. T. and Lugão, S. M. B. 2010. Comportamento e eficiência ingestiva de tourinhos mestiços confinados com três dietas diferentes. Archivos de Zootecnia 59:427-434.

Shiota, A. M.; Santos, S. F.; Nascimento, M. R. B. M.; Moura, A, R. F.; Oliveira, M. V. and Ferreira, I. C. 2013. Parâmetros fisiológicos, características de pelame e gradientes térmicos em novilhas Nelore no verão e inverno em ambiente tropical. Bioscience Journal 29:1687-1695.

Silva, R. G. 2000. Introdução à bioclimatologia animal. Nobel, São Paulo.

Souza, A. N. M.; Rocha, M. G.; Potter, L.; Roso, D.; Glienke, C. L. and Oliveira Neto, R. A. 2011. Comportamento ingestivo de novilhas de corte em pastagem de gramíneas anuais de estação quente. Revista Brasileira de Zootecnia 40:1662-1670. 